\title{
Uprooted by the War: refugees, displaced persons and expellees after World War II
}

\author{
by Göran Rystad
}

\begin{abstract}
Two fundamental changes have taken place during the last decades concerning the refugee question. One is the realization that refugees do not constitute a temporary but a permanent problem. The approach to the immense refugee problems immediately after World War II was to deal with them as temporary problems that could be solved within the next few years and would then not reappear. Thus, the organizations and agencies created to deal with the refugee problems, UNRRA, IRO, UNWRA and others, had specified, limited tasks, and would cease to exist when these tasks were supposed to be completed. The same was largely true also in the case of UNHCR; the transformation of UNHCR from a strictly nonoperational agency with limited resources and short life-expectancy, and with a rather narrowly defined task, to the UNHCR of to-day is the history of this fundamental change, of the realization that refugees are a permanent problem, and there is no hope that this problem will go away in the foreseeable future.

The other basic change in the way in which the refugee question is viewed today compared to the early postwar period is that it is now obvious and understood by all that the refugee problem is a global one, whereas immediately after the war the world's refugee problem seemed to be primarily European.

If we consider the immense refugee problem that existed in Europe immediately after 1945 it must be conceded that the efforts to assist these refugees were comparatively successful. Thus UNRRA managed to repatriate about 6 million Displaced Persons within a few months after the cease-fire. The remaining maybe 850,000 refused repatriation. IRO followed; during the five years it existed it succeeded in assisting more than a million and a half refugees. When UNHCR took over, most of the refugees directly gener-
\end{abstract}

ated by World War II had been repatriated or resettled. However, in addition to those who for various reasons - illness or old age mostly - had not been helped, new refugees had after the war arrived from the East in large numbers.

There is now a common awareness of the fact that the refugees today constitute a major international problem with many facets. At the same time there is a significant amount of confusion concerning how to deal with this problem. States who have signed the same convention interpret it in different ways and the refugee policies pursued present a rather complex and confusing picture. The reasons are partly political (as foreign policy considerations often affect the refugee policy), partly economical, partly related to domestic politics and national public opinion. However, one important aspect of the problem is the origin and historical background of the existing definitions, conventions and practices related to the current refugee policy.

The handling of the acute and grave problems of the refugees during and even more after World War II was, of course, determined or at least heavily influenced by the political developments. At the same time, definitions and classifications in international law played their part. It was a matter of interaction. Political factors influenced legal definitions and implementations. The maybe 10-15 million people in postwar Germany who might have qualified as refugees in the sense that they had been forced to leave their country of former residence, were not treated on an equal footing. A distinction was made between "Displaced Persons", that is individuals who had through German actions been compelled to leave their country for Germany, "Expellees", i.e. Germans who had been forced to leave their former country of residence, their Heimat, as a result of military and political developments and boundary changes in Central and Eastern Europe, and refugees, people who on political, ethnic or religious grounds had fled their country. UNRRA did not concern itself with the Expellees, only with the Displaced Persons. IRO's mandate was to resettle those Displaced Persons who refused to be repatriated. Resettlement was possible for refugees - a meaning which included Displaced Persons - who did not want to be repatriated, and later arrivals from Eastern Europe. Expellees, on the other hand were to be integrated into the German society.

Obviously this categorization was based on political considerations. It was soon to be a matter of contention between the victors of the war. The Soviet Union demanded forcible repatriation of unwilling Displaced Persons, and the issue became one factor in the increasing tensions between the Western Powers and the Soviet Union in the initial stages of the Cold War. Thus, the Soviet Union refused to participate in IRO, and also chose to remain outside UNHCR. There is reason to believe, that today's international definition of the concept "refugee", which emerged in the late 1940s and early 1950s, was heavily influenced by the confrontations of the Cold War. Simultaneously, the convention over the handling of refugees, definitions, categories and implementation, served to add to East-West tensions.

An instructive example of the close connection between, on the one hand, domestic politics and, on the other hand, refugee policy is the manoeuvrering and campaigning surrounding the United States enactment of the Displaced Persons Act of 1948 and its amendment in 1950 . In December, 1945, President Truman proposed the admission of 40,000 Displaced Persons within the existing quota system. However, the regulation was so restrictive - as was the implementation - that only a small number were, in fact, admitted. 
The Displaced Persons Act of 1948 stipulated the admission of 200,000 Displaced Persons, but with severe restrictions and limitations. Thus, only individuals who had been Displaced Persons before December 22, 1945, would be eligible for resettlement in the United States. This would exclude the many later arrivals, of which many were Jews. Also, fifty percent of those admitted had to be from the former Baltic states and 30 percent farmers or farm hands. The amendment passed in 1950 cancelled the restrictions and stipulated an immigration of 400,000 Displaced Persons, to which later 50,000 German Expellees were added.

This change from 1945, over 1948 to 1950 , cannot be ascribed to a change of heart in face of the sufferings of the refugees by the members of the American Coalition and other restrictionist organizations. The resistance against the admission of refugees had as its main basis the same entrenched anti-immigration sentiments, which had made possible the effective restrictionist legislation after World War I. Some of the motives were succinctly summarized in the title of a pamphlet published in 1948 by the President of the American Coalition. The title was "The Displaced Person's Problem: a Menace to Veteran's Housing, the American Standard of Living and Our Political Institutions". Nor can the change from 1945 to 1950 be explained as the result of the diligent work of liberal or ethnic groups represented for example in the umbrella organization "Citizen's Committee on Displaced Persons". Now, we have to look elsewhere for the causal factor behind the swing from an extreme restrictionist stand to a policy of admission, which meant opening the gates for more than a third of a million Displaced Persons in the next two years. It is to be found in the increasing international tension, the polarization between East and West, the Cold War mood. Senator Wiley, (D. Wis.) had been one of the most energetic campaigners for the restrictions of the Displaced Persons Act of 1948. He soon changed his mind and made a total turn around, demanding the speedy removal of the restrictions: "It will be a real inspiration to all free people .... It will be an ideological weapon in our ideological war against the forces of darkness, the forces of communist tyranny", he now argued. Refugees as ideological weapons is also the motive behind the creation in 1952 of USEP, the United States Escapee Program. An indication of the pervasive- ness of concepts, definitions and regulations created in the Cold War era is the fact that for many years to come - and, as a matter of fact, for all practical purposes to this very day - refugees in American refugee policy are people who have fled from or have been forced to leave communist or communist dominated countries.

Another example of the impact of international tensions and power political considerations on refugee policy is the circumstances surrounding the creation of UNHCR and the formulation of the Geneva convention of 1951 . The convention and its definition of the concept refugee was made to fit a Western interpretation of the actual situation; the Soviet Union and its East European satellites refused to participate.

The refugee problem is as many-sided and complex as it is immense. No single research project can deal with it in its entirety, only hope to make a contribution by focusing on a limited part, a specific perspective or a certain aspect of the problem. The project "Uprooted by the War: Refugees, Displaced Persons and Expellees in Europe in the Early Post-War Era" has as its basic theme an international aspect of the development of the refugee policy during the formative, crucial early postwar years. The various studies conducted within the project have one common denominator, namely, a focus on the effect of international politics, tensions, conflicts, rivalries, on refugee policy. The complex nature of the problem makes an interdisciplinary approach appropriate and even necessary. The premise is that in this way a systematic analysis might shed some new light also on the foundations of current international refugee policy.

My own research interest in this context is focused on the linkage between refugee and immigration policies, particularly as it applies to the United States. The point of departure is the belief that restrictionist arguments are basically identical whether it is a matter of admitting refugees or immigrants. I am responsible for another related research project here at Lund, which we have given the title "Encounter with Strangers: Problems Concerning Cultural Confrontations and the Reception of Refugees". The focus is not on the refugees but on attitudes and reactions on the side of the Swedish population. These problems are presently intensely debated in our country. However, our experience is, of course, marginal compared to the United States, where it is at the very centre of the nation's history.

The refugee policy at a given time may be seen as determined by the character and strength of the modifying factors affecting the restrictionist positions. Such modifying factors may be humanitarian, but also ideological or considerations of foreign policy. Of primary importance is also the ethnic and cultural make-up of the refugee populations. The actual American refugee policy after World War II, as well as the legislation, not least the Refugee Act of 1980 and its implementation, may be seen in this perspective.

At first the intention was to limit our research project to the period from the end of the war to 1952 . However, we reached the conclusion that it was necessary to begin at an earlier point. Of special interest was the Intergovernmental Committee on Refugees (IGCR), created on the initiative of the American Government in 1938. IGCR became the most important channel for intergovernmental cooperation on refugee problems until IRO was created in 1947. However, the literature on IGCR is meager. It appears that a comprehensive analysis of the circumstances surrounding the creation of IGCR and also of the Evian and Bermuda conferences in 1938 and 1943, respectively, is worthwhile. It reveals interesting complications of the refugee policy pursued not only by the American government but also for example by the British, facts of interest for an understanding of the conditions prevailing also after the war, not least concerning UNRRA and also IRO.

IGCR was intended to deal exclusively with German and Austrian refugees. However, in 1943 its mandate was broadened to cover all who had been forced to leave their countries of residence as a result of events that had taken place in Europe. It was, in fact, the first attempt to design a general definition of the term "refugee", a point of departure for the latter efforts by IRO and UNHCR in this respect. Tommie Sjöberg is writing his dissertation on IGCR, while Kim Salomon is focusing his study on UNRRA and IRO. Rather intricate relations evolved between these international organizations and, on the one hand, the United Nations and, on the other hand, the governments of the powers involved. The mandate and statutes of UNRRA and even more in IRO, and the way they were implemented became a matter of contention. The comparative success of the organizations in solving problems and completing their 
tasks is rather remarkable in view of the conflicting interests of the Soviet Union and the Western Powers and the escalating Cold War. Salomon's study is not intended to deal with all aspects of the international refugee relief efforts. The focus is - as in the case of all studies within the research project - on the interaction of, on the one hand, international politics, conflicts and tensions and, on the other hand, refugee policy, and on the long-range effects of the development of the early post-war years.

The decision to extend the project beyond 1952, the year UNHCR began to operate, was made early on. A fascinating question is how UNHCR was transformed from its rather impotent early years to a situation where it came to play a key role in refugee affairs with vastly extended resources, a widened range of responsibilities and with broadened mandate. The organization was created in face of strong opposition from the Eastern bloc countries and with a rather weak support from the West. The purpose was mainly to provide legal assistance to refugees in Europe. However, a decade later it also gave significant material assistance to refugees in Third World countries. Important milestones were Hungary in 1956 and Algeria in the early 1960s. Cecilia Ruthström is making a study in depth of the factors that made this development possible. The main focus of the study will be on the late 1950s and especially on two important milestones in the development of UNHCR, the Hungarian crisis in 1956 and the flow of refugees from Algeria to Tunisia and Morocco during the War of Independence. The Hungarian crisis was the first instance where UNHCR undertook a large-scale emergency action for a group, which prima facie was determined to be eligible for refugee status.

This experience was essential when UNHCR then initiated its first emergency operation in a Third World country, in Tunisia in 1957. These two crises mark important steps in the development both of the political conditions under which UNHCR had to act, and of the functions the organization was permitted to perform. Internal factors - decision-making and development of policies within UNHCR - will be observed in the study, as well as factors related to the over-all development of the UN. But not least, in accordance with the general perspective of the project, the analysis will consistently take into account the impact of essential changes in the external environment, the international political development.

The flow of refugees from Hungary in 1956 is also the subject of a special study by Anders Svensson, focusing mainly on problems related to the role and policies of Sweden in this context. There are, among other things, interesting examples of the difference between rhetoric and substance, an analysis of factors such as the role of public opinion, of political expediency and of motives such as considerations of the labour market.

The project "Uprooted by the War" can in a way be described as an attempt to map the international factors which have contributed to the changes over time in the definitions and concepts of refugee and the ensuing international refugee policy. The project is interdisciplinary, and we are happy to among us have Göran Melander, an expert on international law, who is undertaking a study of the changes and developments of these legal concepts and definitions in the postwar era.

Another member of the project, Rune Johansson, has devoted special interest to theoretical implications and problems related to refugee research, to terminology, definitions, and concepts. He has also focused his interest on the flight as a process with the refugee situation as the end result, and worked on a theoretical model of this process, where the emphasis is on the alternative actions open to the refugees and the factors influencing these alternatives.

A disturbing and tragic element of the refugee problems of the last decades has been mass expulsions. Vietnam, Uganda and Cuba provide examples. As Michael Teitelbaum has emphasized, such actions "have become quite deliberate instruments of both domestic and foreign policy for various sovereign nations", and it is unlikely that the past experiences of mass expulsions will be the last.

Mass expulsions belong to different categories. The expellees can be aliens, residents of conquered territory or nationals and citizens. Even if mass expulsions seem to be an increasingly serious threat, they are by no means a new phenomena. Sven Tägil, who has a background of extensive research in ethnic problems, has a special interest in expulsions as manifestations of extreme solutions of ethnic conflicts. There are few if any cases of the same magnitude as the expulsion of Germans, Volksdeutsche as well as Reichsdeutsche, inhabitants of German territory taken over by the Soviet Union,
Poland and Czechoslovakia as a consequence of World War II. Hansáke Persson's study of British refugee policy includes a chapter on how the decision to expel the Germans was made and how it was implemented, particularly British positions and attitudes. The main purpose of his research, however, is an analysis of decision making in London concerning refugee policy and its implementation in the field, in the British occupation zone.

The expellees were no concern of UNRRA or IRO. They could not be resettled but were to be integrated into the German society. This meant an enormous burden on the prostrate people. With the economic recovery the integration started, but an additional strain came with a new type of refugees, hundreds of thousands fleeing from East Germany. The German society and polity thus had to contain millions of Heimatvertriebenen and Zonfluchlinge. The expellees from the East had special interests, regarding their economic and social situation in Germany but also concerning German foreign policy, especially the Ostpolitik, the possibility of a reunion of the two German states and not least the question of German's Eastern boundaries. A matter of interest is to study how a refugee population of this special kind went about organizing itself in order to further and protect its interests, what means were used and what was accomplished, the effect of its activities. Lars Ljunggren is writing his dissertation on this topic.

As stated, there is a close connection between refugee policy and foreign policy. It is a matter of interaction. Not only is refugee policy deeply affected by foreign policy considerations, it can also in its turn adversely affect relations between two countries. A case in point is the protracted conflict between Greece and Yugoslavia over the Greek refugee children. It was a bilateral conflict, closely connected with the process of polarization during the Cold War. It is of interest in this context also because in addition to the usual State and UN actors, a voluntary agency played a key role, the International Red Cross. Kenneth Nyström's research is devoted to this subject.

In addition to these studies one or two others are planned, both focusing on American refugee policy. The position of the United States as the politically dominant power after World War II, and also as the country with unparalleled resources to admit refugees for resettlement, makes it 